\title{
PURIFICATION OF CIRCULATING AND WASTE WATER IN METALLURGICAL INDUSTRY USING COMPLEX COAGULANTS
}

\author{
E. N. Kuzin ${ }^{1}$, N. E. Kruchinina ${ }^{1}$ \\ ${ }^{1}$ Mendeleyev University of Chemical Technology of Russia (Moscow, Russia)
}

\section{E-mail:e.n.kuzin@mail.ru;krutch@muctr.ru}

\section{A UTHOR'S I N FO \\ E. N. Kuzin, Cand. Eng., Department of Environmen- tal Engineering, \\ N. E. Kruchinina, Dr. Eng., Head of Faculty of Biotechnology and Environmental Engineering, Head of Department of Environmental Engineering}

\section{Key words:}

\author{
A B S T RACT
}

\section{Introduction}

Metallurgical production is characterized by large volumes of water consumption [1]. Most part of water is circulated in cooling systems and is not polluted. Gas purification processes occupy the second place by amount of consumed water.

Volumes and pollution of forming waste water after gas purification processes can differ essentially for various plants [1, 2]. Insoluble mineral impurities (suspended substances) are considered as the most common polluting substances. The most part of suspensions has rather large size (more than $50 \mu \mathrm{m}$ ) and is deposited rather quickly in the primary dehydrating box under the effect of gravity force.

Purification of preliminarily enlightened water from fine-dispersed $(1-10 \mu \mathrm{m})$ impurities is quite more complicated task. Deposition time of the particles with $5 \mu \mathrm{m}$ diameter makes $0.01 \mathrm{~mm} / \mathrm{s}(3.6 \mathrm{~cm} / \mathrm{h})$, and for particles with $1 \mu \mathrm{m}-0.1 \mathrm{~cm} / \mathrm{h}$, what increases significantly sizes of dehydrating boxes [3, 4]. Usage of up-to-date thinlayered dehydrating boxes allows to reduce sedimentation time by $25-30 \%$ and equipment size by $60 \%$; however, often it is not sufficient $[5,6]$.

Requirements to water for its reuse differ substantially for various processes, however, increase of salt composition (above $1500 \mathrm{mg} / \mathrm{l}$ ) and content of suspensions and oil products in water above $10 \mathrm{mg} / \mathrm{l}$ and $5 \mathrm{mg} / 1$ respectively are not desirable because it can be harmful for technological equipment.

Reagent water processing (such as coagulation/flocculation) is used most frequently for intensification of deposition processes of such articles. Compounds of $\mathrm{Al}$ or Fe are usually used as coagulants. These coagulants are used for a long time and displayed positive experience in the processes of purification of waste water of various origin. Despite that positive experience, these reagents are characterized by some disadvantages: Fe-containing coagulants lead to corrosion of equipment and involve secondary water pollution by $\mathrm{Fe}$ ions, while $\mathrm{Al}$ compounds can be applied only in the narrow $\mathrm{pH}$ range and are nonefficient at low water temperature [4].

Information about use of titanium-based coagulants in the processes of water purification has been met recently more often. Such coagulants provide sometimes more purification efficiency in smaller amounts and also have not disadvantages usual for traditional reagents [710]. Hydrolysis products of titanium compounds exceed in their efficiency even the most up-to-date aluminium oxychloride [11]. However, usage of pure titanium salts as coagulants is rather expensive and, consequently, is not spread widely.

Usage of complex mixed reagents is considered as prospective direction of physical-chemical purification. Traditional coagulants that are modified by titanium [12] and silicon [13] compounds displayed their high ef- 


\begin{tabular}{|l|c|c|c|c|c|c|}
\hline \multicolumn{1}{|c|}{ Table 1. Chemical composition of waste water samples } \\
\hline \multicolumn{1}{|c|}{ Waste water } & $\begin{array}{c}\text { Total content of sus- } \\
\text { pended particles, } \mathrm{mg} / \mathrm{l}\end{array}$ & $\begin{array}{c}\text { Content of fine-dis- } \\
\text { persed particles, } \mathrm{mg} / \mathrm{l}\end{array}$ & $\mathrm{pH}$ & $\begin{array}{c}\text { Size of fine-dis- } \\
\text { persed fraction, } \mu \mathrm{m}\end{array}$ & $\begin{array}{c}\text { Size of coarse-dis- } \\
\text { persed fraction, } \mu \mathrm{m}\end{array}$ & $\begin{array}{c}\text { Charge } \\
\text { of particles, } \mathrm{mV}\end{array}$ \\
\hline $\begin{array}{l}\text { Gas purification } \\
\text { of coal preparation }\end{array}$ & 2563 & 98.3 & 5.34 & $2.6-3.5$ & $29-103$ & $+(20-25)$ \\
\hline $\begin{array}{l}\text { Gas purification } \\
\text { of electric arc } \\
\text { furnace }\end{array}$ & 9341 & 58.7 & 5.23 & $5.9-7.9$ & $50-270$ & $-(10-18)$ \\
\hline $\begin{array}{l}\text { Gas purification } \\
\text { of coking }\end{array}$ & 3290 & 64.5 & 6.42 & $9.3-12.8$ & $36-190$ & $+(26-29)$ \\
\hline
\end{tabular}

ficiency in purification processes for waste water of various origins.

Usage of complex titanium-bearing reagents for purification of waste water of metallurgical processes seems to be the most prospective research direction, taking into account the fact that such reagents were used with positive feedbacks in purification of waste water of mining and concentration plants [14].

\section{Research objects and methods}

The aim of this research is to evaluate possibility of usage of complex coagulants in the processes of waste water purification in metallurgical production.

The main experimental task is waste water purification to the level meeting the technical requirements of corresponding regulations for circulating water quality as well as comparison of complex coagulant with traditional reagents.

The sample of complex coagulant (CC) obtained via aluminium sulphate modification by hydrolysis products of titanium compounds was selected as the research object. Weight amounts of titanium chlorides were introduced in water solutions of aluminium sulphate; then hydrolysis reaction took place with forming of colloid particles containing of different products of hydrolysis of titanium compounds (reaction 1) [15, 16]. Content of modifying component in CC composition made 5\% (mass.) $\left(\right.$ by $\left.\mathrm{TiO}_{2}\right)$.

$$
\begin{aligned}
& \mathrm{TiCl}_{4} \cdot 5 \mathrm{H}_{2} \mathrm{O} \leftrightarrow \mathrm{Ti}(\mathrm{OH}) \mathrm{Cl}_{3} \cdot 4 \mathrm{H}_{2} \mathrm{O}+\mathrm{HCl} \leftrightarrow \\
& \leftrightarrow \mathrm{Ti}(\mathrm{OH})_{2} \mathrm{Cl}_{2} \cdot 3 \mathrm{H}_{2} \mathrm{O}+\mathrm{HCl} \leftrightarrow \mathrm{Ti}(\mathrm{OH})_{3} \mathrm{Cl} \cdot 2 \mathrm{H}_{2} \mathrm{O}+ \\
& +\mathrm{HCl} \leftrightarrow \mathrm{Ti}(\mathrm{OH})_{4} \cdot \mathrm{H}_{2} \mathrm{O}+\mathrm{HCl}
\end{aligned}
$$

Pure aluminium sulphate and aluminium oxychloride (average basic) was used in samples for comparison.

Testing coagulation was conducted in laboratorial flocculator JLT 4 (VELP), with quick mixing time 2 min, slow mixing time $8 \mathrm{~min}$ and deposition time $30 \mathrm{~min}$. Samples of purified water were analyzed for content of suspended particles.

Efficiency of obtained reagent was evaluated on the following samples of waste water:

- Waste water from gas purification process at the coal preparation shop in the coke chemical plant;
- Waste water from gas purification system at electric steelmaking furnace in the machine-building works;

- Waste water from gas purification process at the coking shop in the coke chemical plant.

Water samples were preliminarily filtered through a net sieve $200 \mu \mathrm{m}$ and dehydrated during $10 \mathrm{~min}$ for separation of coarse particles from quickly depositing fraction.

Content of suspended substances was determined via gravimetric method, and also using portable turbidimeter HANNA (HI 98703-02).

Size and zeta-potential of colloid particles were determined using Zetasizer Nano (Malvern) и Analysette 22 NanoTec (Fritsch) devices.

\section{Experimental results and discussion}

It was revealed on the base of analytical results that suspended particles in waste water forming during the processes of coal preparation and coking are presented by carbon particles, bearing positive charge on their surface, what correlates with bibliographic sources [17]. Oxides of silicon, iron and metals being part of content of alloying compositions were the main components of dispersed particles presented in waste water of the gas purification system in the electric arc furnace. Parameters of water samples are displayed in the Table 1.

Optimal CC dose providing maximal purification efficiency was revealed at the first experimental stage. Efficiency of purification of waste water depending on $\mathrm{CC}$ dose is shown on the Fig. 1.

The Fig. 1 displays that $\mathrm{CC}$ efficient dose does not depend practically on the source of waste water forming or $\mathrm{pH}$ initial value and makes $20 \mathrm{mg} / \mathrm{l}$ summarized for metal oxides. High purification efficiency during $\mathrm{CC}$ usage is caused supposedly by flocculation appearances occurring during polymerization [18] of titanium compounds and nucleation processes $[19,20]$ on the surface particles of products forming during hydrolysis of titanium compounds. These particles had negative charge and lowered surfacial positive charge of coal particles, what played a definite positive role.

Evaluation of summarized purification efficiency was conducted at the next experimental stage for efficient coagulant dose. The efficient dose of CC and aluminium oxychloride made $20 \mathrm{mg} / 1$ (summarized for metals), while for aluminium sulphate it made $25 \mathrm{mg} / \mathrm{l}$ (for $\mathrm{Al}_{2} \mathrm{O}_{3}$ ). The comparing data for maxi- 


\begin{tabular}{|l|c|c|c|c|c|c|}
\hline \multirow{2}{*}{\multicolumn{1}{|c}{ Table 2. Parameters of removal of suspended substances }} \\
\hline \multirow{2}{*}{ Water } & \multicolumn{2}{|c|}{ Time of complete slime deposition, $\mathrm{s}$} & \multicolumn{4}{c|}{ Filtration rate, $\mathrm{ml} / \mathrm{min}$} \\
\cline { 2 - 8 } & $\begin{array}{c}\text { Aluminium } \\
\text { sulphate }\end{array}$ & $\begin{array}{c}\text { Complex } \\
\text { coagulant }\end{array}$ & $\begin{array}{c}\text { Aluminium } \\
\text { oxychloride }\end{array}$ & $\begin{array}{c}\text { Aluminium } \\
\text { sulphate }\end{array}$ & $\begin{array}{c}\text { Complex } \\
\text { coagulant }\end{array}$ & $\begin{array}{c}\text { Aluminium } \\
\text { oxychloride }\end{array}$ \\
\hline Gas purification of coal preparation & 246 & 97 & 119 & 42 & 72 & 61 \\
\hline Gas purification of electric arc furnace & 260 & 85 & 104 & 41 & 92 & 79 \\
\hline Gas purification of coking & 100 & 78 & 98 & 94 & 113 & 98 \\
\hline
\end{tabular}

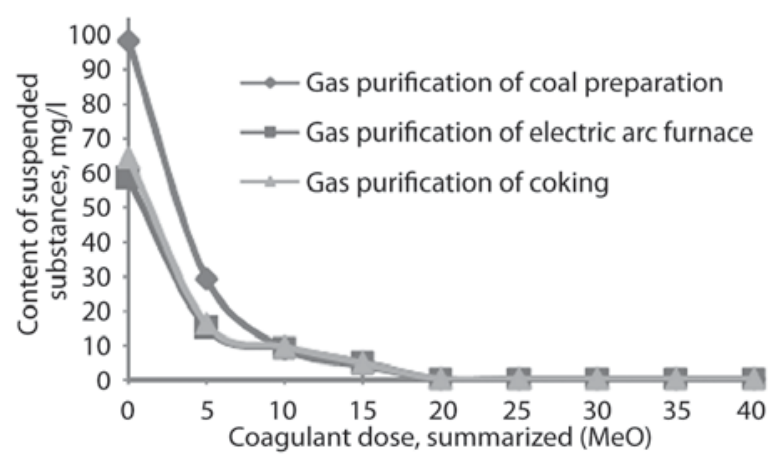

Fig. 1. Influence of complex coagulant (CC) dose on residual content of suspended substances

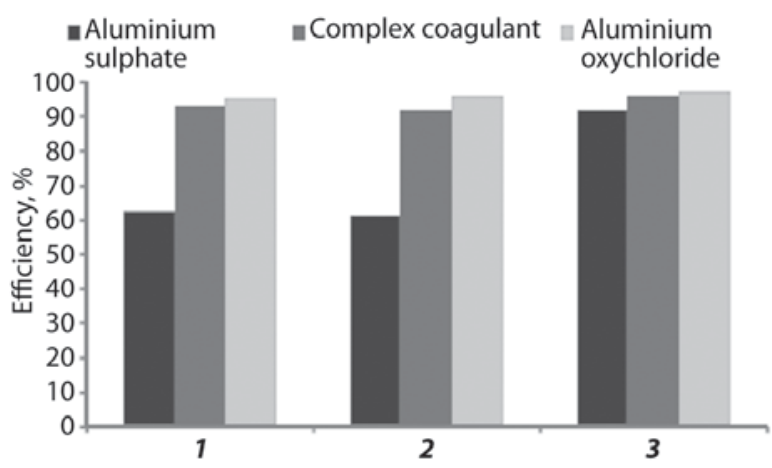

Fig. 2. Comparison of efficiency of coagulants:

1 - gas purification of coal preparation;

2 - gas purification of electric arc furnace;

3 - gas purification of coking

mal achieved purification efficiency are presented on the Fig. 2.

Fig. 2. displays that $\mathrm{CC}$ is comparative in its efficiency with aluminium oxychloride - the most efficient and widely spread at present time. Lowered efficiency of aluminium sulphate is caused by low $\mathrm{pH}$ of processed water.

Addition of titanium compounds can rise efficiency of aluminium sulphate due to specific processes of joint hydrolysis of aluminium sulphate and titanium compounds (increase of hydrolysis rate), forming of wide spectrum of hydrolysis products [15] as well as appearances occurring on the surface of products of hydrolysis of titanium compounds [18-20].

Essential difference in deposition processes (rate of deposition, form and morphology of a sediment) in the process of slime coagulation was noted during experiments.

Filtration rate was measured by pouring of purified water through the filter of "Blue ribbon" type with size of pores 3-5 $\mu \mathrm{m}$. Parameters of sedimentation and filtration of sediment are presented in the Table 2.

Table 2 data testify that usage of CC leads to significant increase of rate of deposition and filtration of coagulation sediments. Probably this appearance is caused by increase of size of forming substances due to flocculating effect of products of hydrolysis of titanium compounds, as well as neutralization and nucleation processes on their surface. This aspect has applied character because it allows to decrease substantially time of slime deposition and filtration and, respectively, sizes of corresponding water purification equipment.

\section{Conclusion}

It can be concluded on the base of obtained experimental results that introduction of products of hydrolysis of titanium compounds in coagulant composition leads to intensification of coagulation processes for dispersed particles of different size and sedimentation process of forming slimes.

It was proved that usage of complex reagents allows to rise substantially purification efficiency in comparison with traditional aluminium sulphate. Complex coagulant has more wide $\mathrm{pH}$ range and does not give up in its efficiency to aluminium oxychloride that is widely used. According to the preliminary economical evaluation, the cost of aluminium oxychloride is higher by $2.0-2.5$ times in average than $\mathrm{CC}$ cost. Besides that, large-scale wastes of high tonnage can be initial raw material for obtaining of complex reagents. Usage of complex coagulants makes it possible to increase significantly deposition rate of suspended particles and to decrease processing time of purifying effluents in dehydrating boxes as well as to reduce their sizes.

Usage of new high-efficient complex reagents (coagulant/flocculant [13] or adsorbent/cationite [21] in purification processes of waste water in metallurgical industry allows to decrease essentially negative effect on hydrosphere. Slime obtained in coagulation process can be used for manufacture of titanium-bearing products [22] and respectively for realization of the waste-free production strategy [23] and putting into practice the best available technologies in metallurgy [24]. 


\section{REFERENCES}

1. Drainage of settlements and industrial enterprises: directory for designer. Edited by V. N. Samokhin. 2nd edition. Moscow. Stroyizdat. 1981. 639 p.

2. Enlarged regulations for water consumption and water disposal for different industries. Moscow. Stroyizdat. 1982.

3. Kuznetsov M. S., Glazunov G. P. Erosion and soil protection. Manual. Moscow. Izdatelstvo MGU. 1996. 335 p.

4. Babenkov E. D. Water cleaning by coagulants. Moscow. "Nauka". 1977. $356 \mathrm{p}$

5. Komarova L. F., Kormina L. A. Engineering methods for environment protection. Technique of atmosphere and hydrosphere protection from industrial pollution. Manual. Barnaul. Izdatelstvo "Altay". 2000. 395 p.

6. Ainetdinov R. M., Vasilyev A. L., Mukhina E. V. Practice of application of thin-walled dehydrating boxes for waste water purification at galvanizing production facilities. Sovremennoe stroitelstvo i arkhitektura. 2016. No. 1. pp. 5-6. DOI: 10.18454/ mca.2016.01.1.

7. Zhao Y. X., Gao B. Y., Zhang G. Z., Qi Q. B., Wang Y., Phuntsho S., Kim J.-H., Shon H. K., Yue Q. Y., Li Q. Coagulation and sludge recovery using titanium tetrachloride as coagulant for real water treatment: A comparison against traditional aluminum and iron salts. Separation and Purification Technology. 2014. Vol. 130. pp. 19-27. DOI: 10.1016/j.seppur.2014.04.015.

8. Zhao Y., Phuntsho S., Gao B. et al., Preparation and Characterization of Novel Polytitanium Tetrachloride Coagulant for Water Purification. Environ. Sci. Technol. 2013. Vol. 47. pp. 12966-12975. DOI: 10.1021/es402708v.

9. Okour Y., Shon H. K., El Saliby I. Characterisation of titanium tetrachloride and titanium sulfate flocculation in wastewater treatment. Water Science and Technology. 2009. No. 59(12). pp. 2463-2473. DOI: 10.2166/wst.2009.254.

10. Zhao Y., Gao B., Shon H., Cao B., Kim J. H. Coagulation characteristics of titanium (Ti) salt coagulant compared with aluminum (Al) and iron (Fe) salts. J. Hazard. Mater. 2011. No. 185. pp. 1536-1542. DOI: 10.1016/j.jhazmat.2010.10.084.

11. Zhao Y. X., Gao B. Y., Cao B. C., Yang Z. L., Yue Q. Y., Shon H. K., Kim J.-H. Comparison of coagulation behavior and floc characteristics of titanium tetrachloride $\left(\mathrm{TiCl}_{4}\right)$ and polyaluminum chloride ( $\mathrm{PACl}$ ) with surface water treatment. Chem. Eng. J. 2011. No. 166. pp. 544-550. DOI: 10.1016/j. jhazmat.2010.10.084.

12. Kruchinina N. E., Kuzin E. N., Azopkov S. V., Chechi- kov I. A., Petrukhin D. Yu. Modification of titanium coagulant via sulphate method. Ekologiya i promyshlennost. 2017. No. 2. pp. 24-27. DOI: 10.18412/1816-0395-2017-2-24-27.

13. Kuzin E. N., Kruchinina N. E. Obtaining of the hardened forms of aluminium-silicate coagulants and their use in water purification and water treatment. Tsvetnye metally. 2016. No. 10. pp. 8-13. DOI: 10.17580/tsm.2016.10.01.

14. Galloux J., Chekli L., Phuntsho S., Tijing L. D., Jeong S., Zhao Y. X., Gao B. Y., Park S. H., Shon H. K. Coagulation performance and floc characteristics of polytitanium tetrachloride and titanium tetrachloride compared with ferric chloride for coal mining wastewater treatment. Sep. Purif. Technol. 2015. No. 152. pp. 94-100. DOI: 10.1016/j.seppur.2015.08.009/

15. Wang T.-H., Navarrete-López A. M., Li S., Dixon D. A., Gole J. L. Hydrolysis of $\mathrm{TiCl}_{4}$ : Initial steps in the production of $\mathrm{TiO}_{2}$. J. Phys. Chem. 2010. A 114 (28). pp. 7561-7570.

16. Luchinskiy G. P. Titanium chemistry. Moscow. Izdatelstvo "Khimiya". 1971. $471 \mathrm{p}$

17. Evmenova G. L. Development of the evaluation method for electric surfacial properties of coaldispersions. Vestnik KuzGTU. 2006. No. 5. pp. 51-53.

18. Shabanova N. A., Popov V. V., Sarkisov P. D. Chemistry and technology of nanodispersed oxides. Manual. Moscow. IKTs “Akademkniga". 2007. 309 p.

19. Draginskiy V. L., Alekseeva L. P., Getmantsev S. V. Coagulation in purification technology of natural water. Moscow. Nauch. Izd. $2005.576 \mathrm{p}$

20. Getantsev S. V., Nechaev I. A., Gandurina L. V. Purification of industrial waste water by coagulants and flocculants. Moscow. ASV. 2008. $271 \mathrm{p}$.

21. Sulimova M. A., Sizyakov V. M., Litvinova T. E., Vasilyev V. V. On possibility of the use of metallurgical production wastes as a sorbent in the industrial water cycle. Chernye metally. 2016. No. 8. pp. 43-49.

22. Shon H., Vigneswaran S., Kandasamy J., Zareie M., Kim J., Cho D., Kim J.H. Preparation and characterization of titanium dioxide $\left(\mathrm{TiO}_{2}\right)$ from sludge produced by $\mathrm{TiCl}_{4}$ flocculation with $\mathrm{FeCl}_{3}, \mathrm{Al}_{2}\left(\mathrm{SO}_{4}\right)_{3}$ and $\mathrm{Ca}(\mathrm{OH})_{2}$ coagulantaids in wastewater. Sep. Sci. Technol. 2009. Vol. 44. pp. 1525-1543. DOI: 10.1080/01496390902775810.

23. Algermissen D., Cankarevich C., Rekersdrees T., Sliephake H., Zehn T. Waste-free strategy at GMH based on four "R" principles. Chernye metally. 2018. No. 6. pp. 46-52.

24. Butorina I. V., Butorina M. V. Issues of implementing the best available technologies in the steel industry of the Russian Federation. Chernye metally. 2019. No. 1. pp. 43-48.

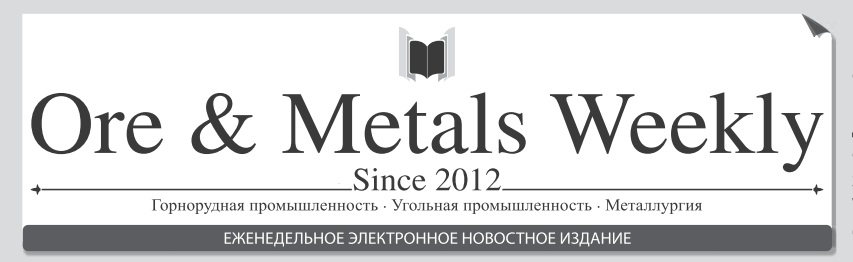

Всем клиентам предлагаем оформить бесплатную подписку на новый продукт Издательского дома «Руда и Металлы» еженедельное новостное электронное издание Ore \& Metals Weekly, распространяемое бесплатно в виде e-mail-рассылки

All customers are invited for free subscription to the new product of "Ore and Metals" Publishing House E-newspaper "Ore \& Metals Weekly" that is distributed free of charge as direct e-mailing.

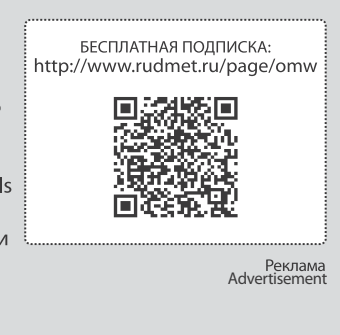

